\title{
Can Disclosure Quality Explain Dividend Payouts?
}

\author{
Dan Lin ${ }^{1}$, Hsien-Chang Kuo ${ }^{2} \&$ Lie-Huey Wang ${ }^{3}$ \\ ${ }^{1}$ Department of Banking and Finance, Takming University of Science and Technology, Taipei, Taiwan \\ ${ }^{2}$ Department of Accounting, and Department of Finance, Shih Chien University, Taipei, Taiwan \\ ${ }^{3}$ Department of Finance, Ming Chuan University, Taipei, Taiwan \\ Correspondence: Lie-Huey Wang, Department of Finance, Ming Chuan University, Taipei, Taiwan. Tel: \\ 886-2-2882-4564 ext. 2191. E-mail: lhwang @ mail.mcu.edu.tw
}

Received: March 7, 2014

doi: $10.5539 /$ ibr.v7n7p10
Accepted: March 24, 2014

Online Publication: June 25, 2014

\begin{abstract}
This study investigates how a firm's disclosure quality affects its dividend policy. Using a sample of Canadian firms with disclosure data from The Globe and Mail, we empirically test the outcome hypothesis and the substitution hypothesis. The outcome hypothesis posits that dividends are an outcome of an effective governance regime and complements other governance mechanisms while the substitution hypothesis argues that dividend payout is a substitute for other forms of governance. Since disclosure quality can reflect the severeness of agency problems between outsiders and insiders, the outcome hypothesis predicts that higher disclosure quality would lead to higher dividend payouts while the substitution hypothesis predicts that lower disclosure quality is associated with higher payouts. This study contributes to the ongoing debate on the relationship between disclosure quality and dividend policy. Our results provide support for the outcome hypothesis; specifically, better disclosure quality is associated with both a stronger propensity to pay dividends and among dividend payers, with larger dividends.
\end{abstract}

Keywords: dividend policy, disclosure, agency problem

\section{Introduction}

The agency theory proposed by Jensen (1986) argues that firms' dividend policies are affected by agency costs. Due to the divergence of ownership and control which leads to agency problems, managers may adopt a dividend policy that serves their self-interests rather than maximizes shareholder value. By distributing dividends to shareholders and reducing the amount of free cash flow, dividend payouts are argued to reduce agency conflicts on two grounds. First, managers are less likely to use the free cash flow for their private benefits (DeAngelo et al., 2006) or to spend the free cash flow on negative net present value investments. The latter is referred to as the agency costs of free cash flow (Jensen, 1986). Secondly, after dividend payouts, when firms have capital needs, they will need to issue new equity or debt. Therefore, firms are exposed to more frequent monitoring by the primary capital markets (Easterbrook, 1984).

Poor disclosure quality increases the agency costs as insiders have more opportunities to expropriate outsiders (Lang et al., 2006). This is because poor disclosure quality inhibits investors from identifying good investments, bad managers and checking the reported accounting performance (Bushman \& Smith, 2001). To study the connection between agency costs and dividends, La Porta et al. (2000) propose an outcome hypothesis and a substitution hypothesis. The outcome hypothesis posits that dividends are paid because of the pressure from minority shareholders on corporate insiders to disgorge cash. Therefore, dividend policy is an "outcome" of an effective corporate governance system. On the other hand, the substitution hypothesis argues that dividends are paid because insiders who plan to issue equity in the future have the incentive to establish a reputation for decent treatment of minority shareholders. Therefore, dividend payouts in this case can be considered as a substitute corporate governance mechanism. Based on La Porta et al.'s (2000) study, we test these two hypotheses on dividend payouts in the context of disclosure quality. According to the outcome hypothesis, a transparent disclosure environment reduces the agency costs and leads to higher dividend payouts as shareholders can monitor firms more closely and demand excess cash flows. In contrast, the substitution hypothesis argues that managers in an opaque disclosure environment give higher payouts as they are to establish a reputation for fair treatment.

A number of studies have examined the relation between disclosure quality and dividend policy. For example, 
Brockman and Unlu (2011) show that firms' disclosure quality has a significant effect on dividend payout and find support for both outcome hypothesis and substitution hypothesis. Adjaoud and Ben-Amar (2010) test the relationship between the propensity to pay dividends and the components of corporate governance score, including board composition, compensation, shareholder rights, and disclosure. Hussainey and Walker (2009) examine the joint effects of dividend propensity and voluntary disclosure on share price anticipation of earnings. Hussainey and Aal-Eisa (2009) examine whether voluntary disclosure and dividends reveal information about future earnings for decline earnings firms after the growth for at least four years. Kowalewski et al. (2008) study the relationship between corporate governance, measured by the Transparency Disclosure Index, and dividend payouts in Poland. Gelb (2000) examines the substitutability among corporate signaling practices including dividends, stock repurchases and accounting disclosures. Gelb (1999) tests if firms' choice of payout methods for one-time cash distribution to shareholders, i.e., special dividends or stock repurchases, is related to the level of accounting disclosures. Arnold (1998) investigates the relation between of information asymmetry and financial disclosure by examining the effect on book returns and dividend cover.

Results from prior studies that test the outcome hypothesis and substitution hypothesis are mixed. Cross-country studies have generally showed support for the outcome hypothesis (La Porta et al., 2000; Faccio et al., 2001; Mitton, 2004; Bae et al., 2012; Bartram et al., 2012). However, conflicting results are found by country-specific studies. Some studies show support for the substitution hypothesis (Hu \& Kumar, 2004; Jiraporn \& Ning, 2006; Officer, 2006; Pinkowitz et al., 2007; Chae et al., 2009; Chang \& Dutta, 2012) while others find evidence for the outcome hypothesis (Kowalewski et al., 2008; Adjaoud \& Ben-Amar, 2010; Jiraporn et al., 2011).

Therefore, the objectives of this study are to examine how disclosure quality influences a firm's dividend payout policy and to provide further evidence on the outcome hypothesis and the substitution hypothesis. Our study contributes to several vital areas of research. First, we contribute to the literature that examines the impact of corporate governance on dividend payouts. While previous studies have used corporate governance indexes (Jiraporn \& Ning, 2006; Chae et al., 2009; Sawicki, 2009; Adjaoud \& Ben-Amar, 2010; Jiraporn et al., 2011; Bae et al., 2012) or several corporate governance related variables, such as board composition, CEO duality, and board size (Campbell and Turner, 2011; Chen et al., 2011; Chang and Dutta, 2012; Abor \& Fiador, 2013) to explain the dividend policy, this study focuses on another aspect of corporate governance issue, disclosure quality, that has received less attention. Second, this study argues that using a corporate governance index suffers from a drawback because it is composed of several aspects of governance (Jiraporn et al., 2011). Each aspect may influence the dividend payouts differently. Certain aspects may have more influence than others. Hence, it is important to look at the index component individually and this study will focus on disclosure quality. Third, while most of prior studies focus on the US markets, it is essential to check the robustness of US results by examining other markets. In this study, we use a sample of Canadian firms. Chang \& Dutta (2012) suggest that the Canadian capital market differs from the US market in three aspects: (1) the ownership by large blockholders in Canada is more concentrated; (2) the Canadian tax system employs a different approach for dealing with investment income; and (3) the Canadian equity market has lower liquidity than the US market. Finally, the current Canadian evidence on the relationship between dividend policy and corporate governance is inconclusive (Adjaoud and Ben-Amar, 2010; Chang \& Dutta, 2012). While Adjaoud and Ben-Amar (2010) find that firms with stronger corporate governance, measured by a corporate governance index, is associated with higher dividends payouts, Chang and Dutta (2012) report that firms with weaker governance characteristics (such as larger board size, lower alignment of CEO pay, CEO duality, and lower CEO ownership) pay higher dividends. Therefore, the issue on disclosure quality and dividend payout is worth further investigation.

\section{Theoretical Background}

\subsection{Corporate Governance and Dividends in an Agency Context}

Both theoretically and empirically prior research has identified a connection between agency costs and dividends payouts (Easterbrook, 1984; Jensen, 1986; Fluck, 1999; Gomes, 2000; La Porta et al., 2000; Lie, 2000; Avivazian et al., 2003, 2006; DeAngelo et al., 2006; Chae et al., 2009; Brockman \& Unlu, 2011; Bartram et al., 2012). La Porta et al. (2000) suggest that in an economy where significant agency problems exist between corporate insiders and outsiders, dividends payouts play an important role.

Grounded in the theory of agency costs of free cash flow, a lot of research has been carried out to examine the link between corporate governance and dividend policy (Easterbrook, 1984; Jensen, 1986; La Porta et al., 2000; Chae et al., 2009; Adjaoud \& Ben-Amar, 2010; Jiraporn et al., 2011; Officer, 2011; Bae et al., 2012; Bartram et al., 2012; Chang \& Dutta, 2012; Abor \& Fiador, 2013). Easterbrook (1984) argues that dividend payouts can help reduce agency costs by exposing firms to more frequent monitoring by the primary capital markets. According to La Porta 
et al. (2000), dividends can be viewed as an "outcome" of an effective corporate governance system or a "substitute" for weak governance. Using shareholder protection as a proxy for agency problems, La Porta et al. (2000) test if dividends can be considered as an "outcome" or a "substitute" of legal protection of shareholders. Under the first view where dividends are considered as an outcome of an effective legal protection system for shareholders, minority shareholders use their legal power to force companies to distribute excess cash and to refrain managers from using the excess cash to generate private benefits that are not shared by minority shareholders. By paying out dividends to shareholders, the agency costs of free cash flow are reduced (Jensen, 1986).

Under the second view which assumes that firms have the need to raise funds in the external capital markets, dividends are a substitute for legal protection and are paid out by managers to establish a reputation for good treatment of shareholders when the country has weak legal protection of minority shareholders. Prior studies show that weakly governed managers are more likely to engage in dividend smoothing (Knyazeva, 2007) and face greater pressure from shareholders to pay dividends (John \& Knyazeva, 2006). In a cross-country analysis, Pinkowitz et al. (2007) show that minority shareholders add a premium value on dividends when there is low investor production.

Firms with poor investment opportunities (low Tobin's Q) and ample resources (high cash flow) arguably suffer from greater agency problems (Officer, 2011). The overinvestment hypothesis suggests that these firms are more likely to overinvest or waste the shareholders' cash. Distributing dividends can therefore be perceived as a way of reducing agency costs (Easterbrook, 1984; Jensen, 1986). Officer (2011) find support for the overinvestment hypothesis and reports that firms with low investment opportunities and high cash flow are associated with more positive dividend initiation announcement returns. The results from Officer (2011) are also consistent with the substitution hypothesis which argues that dividend payout is a substitute governance mechanism for alleviating agency problems.

A number of studies (Fama and French, 2001; Grullon et al., 2002; DeAngelo \& DeAngelo, 2006; DeAngelo et al., 2006; Brockman \& Unlu, 2011) have advanced the lifecycle explanations for dividends. The lifecycle theory suggests that firms adjust their dividend payout through time. As firms mature, the tradeoff between the advantage of retaining free cash flow arisen from declining information costs and the disadvantage of rising agency costs that encourages payout evolves over time (DeAngelo et al., 2006; Brockman \& Unlu, 2011; Armitage, 2012). As young firms have more investment opportunities but are short on cash, they are more inclined to retain cash in order to avoid the costs associated with raising external capital. On the other hand, mature firms have higher profitability and more cash, but face fewer investment opportunities, so they have stronger incentives to distribute cash to shareholders through, for example, dividends to reduce the agency costs of free cash flow.

Moreover, due to diminishing returns, Araujo et al. (2011) argue that the cost of dividend is lower for high earnings firms. Therefore, the traditional "investment effect" predicts that high earnings firm would pay higher dividends. However, Araujo et al. (2011) propose another explanation, "productivity effect", for dividend policy. By extending Miller and Rock's (1985) model and incorporating future productivity of the firm, Araujo et al. (2011) argue that due to the productivity effect, high earnings firms may not pay high dividends because the sacrifice of investment due to dividend payout represents a greater cost for higher productivity firms. Accordingly, dividend payout may be lower for mature firms.

\subsection{Disclosure and Dividends}

The fundamental premise of this study is that in a world of significant agency problems between corporate insiders and outsiders, there should be an economic association between disclosure quality and dividend payouts. Based on the above review of literature, there are two opposing views on the relationship between disclosure quality and dividend payouts in an agency context (La Porta et al., 2000; Brockman \& Unlu, 2011; Jiraporn et al., 2011; Bartram et al., 2012; Chang \& Dutta, 2012). On the one hand, the dividend policy is perceived as an outcome of the disclosure quality; that is, the outcome hypothesis. In an opaque disclosure environment, managers are more likely to conduct opportunistic behavior and the agency costs of free cash flow, suggested by Jensen (1986), are likely to occur. Managers of firms with weaker governance and lower disclosure quality are more likely to abuse the free cash flow, pay out less cash to shareholders, spend the free cash flow on empire building and negative net present value projects and consume perquisites. In contrast, firms with higher disclosure quality are more likely to pay larger dividends because shareholders are better able to find out the level of excess cash flow in a transparent disclosure environment and demand for higher dividend payouts. Therefore, based on the outcome hypothesis, a positive relationship between disclosure quality and dividend payouts is expected.

On the other hand, dividend payout and disclosure are considered as substitute mechanisms for alleviating the 
conflicts of interests between managers and shareholders; that is, the substitution hypothesis. This hypothesis argues that firms with lower disclosure quality are more susceptible to managerial entrenchment and are likely to incur the agency costs of free cash flow. Hence, in an opaque disclosure environment where the agency problem is more severe, shareholders would demand higher dividend payouts and managers would increase payouts to establish their reputation for fair treatment. Therefore, based on the agency theory, the substitution hypothesis posits a negative relationship between disclosure quality and dividend payouts. Moreover, from the signaling perspective, dividend can be is a credible signal when there is high information asymmetry (Booth and Chang, 2011; Cheng et al., 2011). Firms with higher disclosure quality can reduce the extent of information asymmetry between managers and outsiders. Therefore, firms operating in a more transparent disclosure environment have less need to signal firm quality using dividends and have lower dividend payouts. Therefore, based on the signaling effect, disclosure quality is expected to be negatively associated with dividend payouts.

\subsection{Empirical Evidence on the Outcome Hypothesis and Substitution Hypothesis}

Studies that find support for the outcome hypothesis include, for example, Jiraporn et al. (2011) who report that firms with better governance quality have a stronger propensity to pay dividends and among dividend-paying firms, better governed firms pay larger dividends. Adjaoud and Ben-Amar (2010) show that firms with stronger governance have higher dividend payouts. In particular, the board composition and shareholder rights' policy of the four corporate governance index components are positively related to payout ratios. Kowalewski et al. (2008) also find evidence consistent with the outcome hypothesis using a sample of Poland companies and the Transparency Disclosure Index (TDI) as a proxy for corporate governance practices. In particular, they find a positive relationship between dividend to cash flow ratio and the TDI or its sub-indices. Further, Mitton (2004) reveals that in emerging markets, firms with stronger corporate governance have higher dividend payouts, but such positive relationship is limited to countries with strong investor protection.

There are also studies that find evidence supporting the substitution hypothesis. For example, Chang and Dutta (2012) examine the Canadian firms and find that firms with weaker governance pay higher dividends. Chae et al. (2009) report that the relationship between dividend payout and corporate governance is negative and depends on the relative size of agency costs and external financing constraints. Jiraporn and Ning (2006) show an inverse relation between dividend payouts and shareholder rights. Officer $(2006,2011)$ provides evidence for the substitution hypothesis. Based on a sample of firms that should pay dividends, Officer (2006) reveals that dividend policy is a substitute for weak internal and external governance. In addition, Officer (2011) finds that firms with weak governance and firms with poor investment opportunities and high cash flow are associated with more positive dividend initiation announcement returns.

Moreover, some studies even find support for both the outcome hypothesis and the substitution hypothesis. Sawicki (2009) finds that prior to the Asian financial crisis there is some evidence of substitution effect between dividends and corporate governance mechanisms. However, the relationship between corporate governance and dividends is reversed and turns positive in the post-crisis period, providing support for the outcome hypothesis. Brockman and Unlu (2011) report a U-shape relation between dividend payouts and disclosure quality and provide supports for both hypotheses. They argue that in an opaque disclosure environment, managers may pay higher dividends as a way of establishing their reputation among capital providers; that is, the substitution hypothesis. In a transparent disclosure environment, managers are under the close eye of outside investors and are more likely to disgorge the excess cash; that is, the outcome hypothesis. The link between disclosure quality and dividends payouts is found to be weakest when the disclosure environment is not extremely transparent or opaque.

\section{Method}

\subsection{Hypotheses}

The outcome and substitution hypotheses have opposite predictions about the relation between disclosure and dividend policy. The outcome hypothesis predicts that firms with higher disclosure quality are more likely to pay dividends and in larger amounts. On the other hand, the substitution hypothesis predicts that lower disclosure quality is associated with stronger propensity to pay dividends and higher dividend payouts. The testable hypotheses are as follows:

Hla (outcome): Firms with higher disclosure quality are more likely to pay dividends.

$H 1 b$ (substitution): Firms with lower disclosure quality are more likely to pay dividends.

H2a (outcome): Firms with higher disclosure quality have higher dividend payouts.

$H 2 b$ (substitution): Firms with lower disclosure quality have higher dividend payouts. 


\subsection{Data}

The initial sample consists of firms listed on the S\&P/TSX composite index with disclosure rankings in The Globe and Mail (G\&M) for the period 2009-2012. The Globe and Mail has published annual scores of corporate governance practices of Canadian publicly listed firms since 2002 and examines four facets of corporate governance, including board composition, shareholding and compensation, shareholder rights and disclosure (Ben-Amar \& Zeghal, 2011). The reason for choosing this sample period 2009-2012 is that there were changes to the disclosure index with additions of several questions in 2009 and in 2013. The maximum disclosure score that a company can obtain increased from 10 marks to 12 marks in 2009 and to 13 marks in 2013. Several prior Canadian studies have used the rankings produced by G\&M to study, for example, the relationship between disclosure and board independence (Ben-Amar \& Zeghal, 2011), corporate governance and dividend policy (Adjaoud \& Ben-Amar, 2010), corporate governance and firm value (Klein et al., 2005; Adjaoud et al., 2007), corporate governance and earnings quality (Niu, 2006), and corporate governance and ownership structure (Bozec $\&$ Bozec, 2007). Firms that do not have all the required financial and accounting data available on the Standard \& Poor's Compustat database are eliminated from the sample. The final sample consists of 664 firm year observations. Table 1 presents an industrial breakdown of our sample firms.

Table 1 . Sample firms by industry

\begin{tabular}{lcc}
\hline Industry & No. of obs & $\%$ \\
\hline Mining and construction & 240 & 36.1 \\
Manufacturing & 100 & 15.1 \\
Transportation, Communications, Electric, Gas, And Sanitary Services & 92 & 13.9 \\
Wholesale Trade and Retail Trade & 64 & 9.6 \\
Finance, Insurance, And Real Estate & 144 & 21.7 \\
Services & 24 & 3.6 \\
\hline Total & 664 & 100 \\
\hline
\end{tabular}

\subsection{Models}

To examine the linkage between disclosure quality and dividend policy, this study utilizes two models as shown below: (1) a logit regression model, which is used to examine the effect of disclosure quality on the likelihood of dividend payouts, and (2) a panel regression model, which is used to examine the relationship between disclosure quality and dividend payouts for dividend-paying firms. The dependent variable of Model 1 is the likelihood of the firm paying dividends (DIVD) and is set to 1 if the firm pays a dividend, and 0 otherwise. The logit function where the probability of DIVD is estimated using the functional form $\pi(\mathrm{x})=\mathrm{e}^{\mathrm{g}(\mathrm{x})} / 1+\mathrm{e}^{\mathrm{g}(\mathrm{x})}$. The dependent variable of Model 2 is the ratio of cash dividends to total assets $(D I V)$. Other dividend measures such as dividend to cash flow and dividend payout ratio (defined as dividends to earnings) can become unstable when the cash flow or earnings is close to zero (Chang \& Dutta, 2012). The measure of dividend yield (defined as dividends to price) can also be confounded by market perceptions and pricing effects (Chang \& Dutta, 2012).

$$
\begin{aligned}
& P(D I V D)_{i t}=f\left\{\alpha_{i}+\beta_{1} D_{S C O R E_{i t}}+\beta_{2} L A G(D I V)_{i t-I}+\beta_{3} \operatorname{Ln}(T A)_{i t}+\beta_{4} L_{E V E R A G E_{i t}}+\beta_{5} R_{0} E_{i t}+\beta_{6} \text { CAPEXP }_{i t}+\right. \\
& \left.\beta_{7} M B_{i t}+\beta_{8} \text { TAX }_{i t}+\beta_{9} \text { RETAIN }_{i t}+\beta_{I 0} \text { CASH }_{i t}+\beta_{I I} \text { INDUSTRY }_{i}+\varepsilon_{i}\right\} \\
& D I V_{i t}=\alpha_{i}+\beta_{1} D_{S C O R E_{i t}}+\beta_{2} L A G(D I V)_{i t-1}+\beta_{3} L n(T A)_{i t}+\beta_{4} L E V E R A G E_{i t}+\beta_{5} R O E_{i t}+\beta_{6} \text { CAPEXP }_{i t}+\beta_{7} M_{i t}+ \\
& \beta_{8} \text { TAX }_{i t}+\beta_{9} \text { RETAIN }_{i t}+\beta_{10} \text { CASH }_{i t}+\beta_{11} \text { INDUSTRY }_{i}+\varepsilon_{i}
\end{aligned}
$$

Table 2 presents a description of all relevant dependent, independent and control variables used in the analyses. The disclosure quality is measured by the disclosure score obtained from the G\&M. The G\&M evaluates the quality of information disclosed by companies about its corporate governance practices (Adjaoud \& Ben-Amar, 2010). For example, marks are granted to companies that provide a full explanation of which directors are related and unrelated and that explain how each director's share ownership meets (or fails to meet) the required share ownership guideline (Board Games 2012: Methodology, 2012). The maximum score for disclosure quality is 12.

Based on a review of prior literature on dividend policy, we control for variables that have impacts on dividend payouts in our analyses. First, we control for a one-year lagged dividend as prior research shows that dividend paying companies have the tendency to maintain a stable payout policy over time (Lintner, 1956; Adjaoud \& 
Ben-Amar, 2010). Firm size, measured by natural logarithm of total assets, is also controlled for. Larger firms arguably have more access to outside resources and are less dependent on internal funds (Fama \& French, 2001; Denis \& Osobov, 2008). Therefore, larger firms are more likely to pay dividends and in larger amounts. Leverage, defined as the ratio of total debt to total assets, is controlled for because debt can also be considered as a corporate governance mechanism for alleviating the potential free cash flow problem (Renneboog \& Trojanowski, 2007; Setia-Atmaja et al., 2009). Also, there may be debt covenants on dividends imposed by debt holders (Jiraporn et al., 2011). Therefore, a negative relationship is expected between leverage and dividend payouts.

Table 2. Variable descriptions

\begin{tabular}{|c|c|c|c|}
\hline Variable & Symbol & Exp Sign & Description \\
\hline \multicolumn{4}{|l|}{ Dependent variables } \\
\hline Dividend dummy (Logit) & $D I V D$ & & Dummy variable that equals one if the firm pays a dividend. \\
\hline Dividend (Panel) & $D I V$ & & Ratio of cash dividends to total assets. \\
\hline \multicolumn{4}{|l|}{ Independent variable } \\
\hline Disclosure quality & DSCORE & $+/-$ & $\begin{array}{l}\text { Disclosure score is collected from The Globe and Mail. This } \\
\text { variable ranges from } 0 \text { to } 12 \text {. }\end{array}$ \\
\hline \multicolumn{4}{|l|}{ Control variables } \\
\hline Lagged dividends & $L A G(D I V)$ & + & One-year lagged dividend (t-1). \\
\hline Firm size & $\operatorname{Ln}(T A)$ & + & Natural logarithm of total assets. \\
\hline Leverage & LEVERAGE & - & Ratio of total debt to total assets. \\
\hline Profitability & $R O E$ & + & Ratio of net income to shareholders' equity. \\
\hline Growth opportunities & CAPEXP & - & Ratio of capital expenditure to total assets. \\
\hline Investment opportunities & $M B$ & - & $\begin{array}{l}\text { Ratio of market value of equity plus the book value of debt to } \\
\text { the book value of assets. }\end{array}$ \\
\hline Taxation & $T A X$ & - & Ratio of income tax to total assets. \\
\hline Retained earnings & RETAIN & + & Ratio of retained earnings to total equity. \\
\hline \multirow[t]{2}{*}{ Availability of cash } & $\mathrm{CASH}$ & + & $\begin{array}{l}\text { Ratio of cash and marketable securities to net assets, which are } \\
\text { total assets minus cash and short-term securities }\end{array}$ \\
\hline & $F C F$ & + & Ratio of free cash flow to book value of assets. \\
\hline Industry dummy & INDUSTRY & $+/-$ & Dummy variables for industrial sectors. \\
\hline
\end{tabular}

Moreover, firms with higher profitability have more net income available for distributing cash dividends to shareholders (Chang \& Dutta, 2012). Hence, we control for profitability using ROE and a positive relationship with dividend payout is expected. Firms with higher growth opportunities (measured by the ratio of capital expenditure to total assets) and investment opportunities (measured by the ratio of market value of equity plus the book value of debt to the book value of assets) have more cash flow needs for future investment and operating activities (Adjaoud \& Ben-Amar, 2010; Chang \& Dutta, 2012). Therefore, growth opportunities and investment opportunities are expected to be negatively associated with dividend payouts.

Higher tax will reduce the profits and thereby the amount of cash available for paying out to shareholders (Abor \& Fiador, 2013). Therefore, in this study we include a taxation variable, defined as the ratio of income tax to total assets, to account for such effect. In addition, we include retained earnings, defined as the ratio of retained earnings to total equity, as the control variable because mature firms that have more earned capital than contributed capital are more likely to pay larger dividends (Jiraporn et al., 2011). DeAngelo et al. (2006) also show that the ratio of earned to contributed capital mix is a significant determinant of dividend payout. According to Jensen (1986), firms may distribute cash to shareholders through dividend payouts as a way of reducing the agency costs of free cash flow. This study controls for the availability of free cash using two alternative measures, (1) the ratio of cash and marketable securities to net assets and (2) the ratio of free cash flow to book value of 
assets (where free cash flow is measured by the net cash flow from operating activities minus cash dividends and capital expenditures). To control for possible variations across industries, we include dummy variables for industry sectors based on the first-two digit SIC codes.

\section{Results}

\subsection{Descriptive Statistics}

Table 3 shows the summary statistics for the sample firms. Our sample consists of 664 firm year observations (including 532 dividend paying firms and 132 nonpaying firms). The average disclosure score of sample firms is 8 (out of a total score of 12). The correlations in Table 4 show that dividend is positively related to leverage, profitability, investment opportunities and taxation, and is negatively associated with retained earnings and cash. Inconsistent with the prediction, the results suggest that leverage is not a substitute governance mechanism for reducing the agency costs of free cash flow. Instead, the results indicate that firms are likely to raise debt in order to maintain its dividend level, reflecting the "stickiness" in dividend payouts that have been discussed in previous literature (Guttman et al., 2010; Twu, 2010). Interestingly, our results suggest that growth firms are associated with higher dividend payouts while mature firms with high retained earnings are associated lower payouts. The latter evidence is consistent with the "productivity effect" suggested by Araujo et al. (2011). Specifically, we find that dividend is positively, but insignificantly, associated with growth opportunities and has a strong positive relationship with investment opportunities while retained earnings is negatively related to dividend. Moreover, the results show that firms with higher (or lower) cash are associated with lower (or higher) dividends. There are two possible explanations for the inverse relationship between cash and dividends. First, the evidence may suggest that our sample firms are more likely to suffer from the agency costs of free cash flow. Second, firms with low cash may insist in paying high dividends due to the stickiness nature of dividend payouts and the signaling effect of dividend policy.

Table 3. Descriptive statistics

\begin{tabular}{|c|c|c|c|c|c|c|}
\hline & Obs & Mean & Median & Std. Dev. & Min & Max \\
\hline DIV & 664 & 0.02 & 0.01 & 0.03 & 0.00 & 0.23 \\
\hline DISCORE & 664 & 8.35 & 9.00 & 3.10 & 0.00 & 12.00 \\
\hline LAG(DIV) & 664 & 213.78 & 58.14 & 413.68 & 0.00 & 3049.00 \\
\hline $\operatorname{Ln}(\mathrm{TA})$ & 664 & 8.58 & 8.19 & 1.65 & 5.43 & 13.62 \\
\hline LEVERAGE & 664 & 21.47 & 19.61 & 15.67 & 0.00 & 74.11 \\
\hline ROE & 664 & 9.60 & 10.10 & 20.21 & -250.29 & 278.08 \\
\hline CAPEXP & 664 & 0.08 & 0.06 & 0.07 & 0.00 & 0.42 \\
\hline MB & 664 & 1.28 & 1.09 & 0.84 & 0.06 & 5.35 \\
\hline TAX & 664 & 0.02 & 0.01 & 0.02 & -0.15 & 0.20 \\
\hline RETAIN & 664 & 0.18 & 0.34 & 1.05 & -17.36 & 0.94 \\
\hline CASH & 664 & 0.13 & 0.05 & 0.28 & 0.00 & 3.66 \\
\hline FCF & 664 & -0.01 & 0.00 & 0.08 & -0.44 & 0.38 \\
\hline No of DIV payers & 532 & & & & & \\
\hline
\end{tabular}

DIV: Ratio of cash dividends to total assets; DISCORE: Disclosure score collected from The Globe and Mail; LAG(DIV): One-year lagged dividend; $\operatorname{Ln}(T A)$ : Natural logarithm of total assets; $L E V E R A G E$ : Ratio of total debt to total assets; ROE: Ratio of net income to shareholders' equity; $C A P E X P$ : Ratio of capital expenditure to total assets; $M B$ : Ratio of market value of equity plus the book value of debt to the book value of assets; TAX: Ratio of income tax to total assets; RETAIN: Ratio of retained earnings to total equity; CASH: Ratio of cash and marketable securities to net assets, which are total assets minus cash and short-term securities; $F C F$ : Ratio of free cash flow to book value of assets. 
Table 4. Correlation analysis

\begin{tabular}{|c|c|c|c|c|c|c|c|c|c|c|}
\hline & DIV & LAG(DIV) & LEVERAGE & ROE & CAPEXP & MB & TAX & RETAIN & CASH & FCF \\
\hline DIV & 1.00 & & & & & & & & & \\
\hline LAG(DIV) & 0.00 & 1.00 & & & & & & & & \\
\hline LEVERAGE & $0.15 * * *$ & -0.02 & 1.00 & & & & & & & \\
\hline ROE & $0.18 * * *$ & $0.08 * *$ & 0.01 & 1.00 & & & & & & \\
\hline CAPEXP & 0.02 & $-0.21 * * *$ & $-0.07 *$ & $-0.07 *$ & 1.00 & & & & & \\
\hline MB & $0.35 * * *$ & $-0.30 * * *$ & $-0.11 * * *$ & 0.05 & $0.31 * * *$ & 1.00 & & & & \\
\hline TAX & $0.20 * * *$ & $-0.14 * * *$ & $-0.21 * * *$ & $0.25 * * *$ & $0.14 * * *$ & $0.32 * * *$ & 1.00 & & & \\
\hline RETAIN & $-0.13 * * *$ & $0.11 * * *$ & $-0.22 * * *$ & $0.14 * * *$ & -0.02 & $-0.19 * * *$ & $0.08 * *$ & 1.00 & & \\
\hline CASH & $-0.09 * *$ & $-0.11 * * *$ & $-0.25 * * *$ & $-0.06 *$ & -0.01 & $0.27 * * *$ & $0.09 * *$ & -0.04 & 1.00 & \\
\hline FCF & 0.03 & 0.04 & -0.05 & $0.20 * * *$ & $-0.61 * * *$ & -0.06 & $0.29 * * *$ & $0.10 * * *$ & -0.02 & 1.00 \\
\hline
\end{tabular}

DIV: Ratio of cash dividends to total assets; $L A G(D I V)$ : One-year lagged dividend; LEVERAGE: Ratio of total debt to total assets; ROE: Ratio of net income to shareholders' equity; CAPEXP: Ratio of capital expenditure to total assets; $M B$ : Ratio of market value of equity plus the book value of debt to the book value of assets; TAX: Ratio of income tax to total assets; RETAIN: Ratio of retained earnings to total equity; CASH: Ratio of cash and marketable securities to net assets, which are total assets minus cash and short-term securities; FCF: Ratio of free cash flow to book value of assets. $*, * *, * * *$ denote significance at the $10 \%, 5 \%$ and $1 \%$ levels, respectively.

\subsection{Multivariate Analysis}

We use a logit regression to investigate the relationship between disclosure quality and dividend policy as shown in Table 5. The dependent variable is a dichotomous variable that equals one if the firm pays dividends. The variable of interest is DSCORE, which proxies for disclosure quality. The coefficient of this variable is positive and significant for both models, suggesting that firms with better disclosure quality exhibit a higher probability to pay dividends. The evidence is thus in line with the outcome hypothesis where shareholders are able to force managers to disgorge cash in the form of dividends in a transparent disclosure environment.

In Table 6, we utilize panel analysis and the random effects model to investigate the impact of disclosure quality on the magnitude of dividend payouts. DSCORE displays significant and positive coefficients only for Model 2 where FCF is used a proxy for the availability of cash. The FCF arguably is a closer measure of the agency costs of free cash flow problem. Therefore, the result provides evidence supporting the outcome hypothesis. Specifically, the results suggest that in a more transparent disclosure environment where the agency costs are lower, firms pay larger dividends. Overall, better disclosure quality is associated with both a stronger propensity to pay dividends and among dividend payers, with larger dividends. 
Table 5. The likelihood of dividend payouts and disclosure quality

\begin{tabular}{|c|c|c|}
\hline & Model 1 & Model 2 \\
\hline \multirow[t]{2}{*}{ Intercept } & $-7.007 * * *$ & $-7.737 * * *$ \\
\hline & $(-4.189)$ & $(-4.661)$ \\
\hline \multirow[t]{2}{*}{ DSCORE } & $0.219 * * *$ & $0.214 * * *$ \\
\hline & $(4.571)$ & $(4.460)$ \\
\hline \multirow[t]{2}{*}{ LAG(DIV) } & $0.007 * * *$ & $0.007 * * *$ \\
\hline & $(2.783)$ & $(2.720)$ \\
\hline \multirow[t]{2}{*}{$\operatorname{Ln}(\mathrm{TA})$} & $0.327 *$ & $0.394 * *$ \\
\hline & (1.782) & $(2.162)$ \\
\hline \multirow[t]{2}{*}{ LEVERAGE } & $0.048 * * *$ & $0.050 * * *$ \\
\hline & (3.635) & $(3.920)$ \\
\hline \multirow[t]{2}{*}{ ROE } & $0.011 *$ & 0.009 \\
\hline & $(1.772)$ & (1.389) \\
\hline \multirow[t]{2}{*}{ CAPEXP } & $-5.427 * * *$ & -1.189 \\
\hline & $(-2.587)$ & $(-0.423)$ \\
\hline \multirow[t]{2}{*}{ MB } & $0.370 * *$ & $0.318 *$ \\
\hline & $(2.065)$ & $(1.761)$ \\
\hline \multirow[t]{2}{*}{ TAX } & $26.692 * * *$ & $22.276 * * *$ \\
\hline & $(4.434)$ & (3.389) \\
\hline \multirow[t]{2}{*}{ RETAIN } & $0.359 * * *$ & $0.353 * * *$ \\
\hline & (3.149) & (3.075) \\
\hline \multirow[t]{2}{*}{ CASH } & -0.654 & \\
\hline & $(-1.282)$ & \\
\hline \multirow[t]{2}{*}{ FCF } & & $4.341 *$ \\
\hline & & (1.951) \\
\hline Industry dummies & Yes & Yes \\
\hline McFadden $\mathrm{R}^{2}$ & 0.466 & 0.469 \\
\hline Log likelihood & -176.760 & -175.799 \\
\hline Total obs & 664 & 664 \\
\hline
\end{tabular}

This table reports the result of the Logit regression models. Dependent variable (DIVD): Dummy variable that equals one if the firm pays a dividend. DSCORE: Disclosure score collected from The Globe and Mail. DIV: Ratio of cash dividends to total assets; LAG(DIV): One-year lagged dividend; $L n(T A)$ : Natural logarithm of total assets; LEVERAGE: Ratio of total debt to total assets; ROE: Ratio of net income to shareholders' equity; CAPEXP: Ratio of capital expenditure to total assets; $M B$ : Ratio of market value of equity plus the book value of debt to the book value of assets; TAX: Ratio of income tax to total assets; RETAIN: Ratio of retained earnings to total equity; CASH: Ratio of cash and marketable securities to net assets, which are total assets minus cash and short-term securities; FCF: Ratio of free cash flow to book value of assets. $z$-statistics are reported in parentheses. ${ }^{*}, * *, * * *$ denote significance at the $10 \%, 5 \%$ and $1 \%$ levels, respectively. 
Table 6. Dividend payouts and disclosure quality for dividend payers

\begin{tabular}{|c|c|c|}
\hline & Model 1 & Model 2 \\
\hline \multirow[t]{2}{*}{ Intercept } & $0.103 * * *$ & $0.098 * * *$ \\
\hline & (8.336) & (8.307) \\
\hline \multirow[t]{2}{*}{ DSCORE } & 0.000 & $0.000 * *$ \\
\hline & $(1.320)$ & $(2.033)$ \\
\hline \multirow[t]{2}{*}{ LAG(DIV) } & $0.000 * * *$ & $0.000 * * *$ \\
\hline & $(6.089)$ & $(6.161)$ \\
\hline \multirow[t]{2}{*}{$\operatorname{Ln}(\mathrm{TA})$} & $-0.012 * * *$ & $-0.012 * * *$ \\
\hline & $(-10.227)$ & $(-10.319)$ \\
\hline \multirow[t]{2}{*}{ LEVERAGE } & 0.000 & 0.000 \\
\hline & $(1.184)$ & $(1.040)$ \\
\hline \multirow[t]{2}{*}{ ROE } & 0.000 & 0.000 \\
\hline & $(0.309)$ & $(0.460)$ \\
\hline \multirow[t]{2}{*}{ CAPEXP } & $0.032 * *$ & -0.008 \\
\hline & $(2.103)$ & $(-0.426)$ \\
\hline \multirow[t]{2}{*}{ MB } & $0.007 * * *$ & $0.008 * * *$ \\
\hline & $(5.419)$ & (5.989) \\
\hline \multirow[t]{2}{*}{ TAX } & 0.044 & $0.060 * *$ \\
\hline & $(1.575)$ & (2.118) \\
\hline \multirow[t]{2}{*}{ RETAIN } & $0.002 * * *$ & $0.002 * * *$ \\
\hline & $(3.210)$ & $(2.897)$ \\
\hline \multirow[t]{2}{*}{ CASH } & $-0.009 * *$ & \\
\hline & $(-2.007)$ & \\
\hline \multirow[t]{2}{*}{ FCF } & & $-0.046 * * *$ \\
\hline & & $(-4.101)$ \\
\hline Industry dummies & Yes & Yes \\
\hline Adjusted $R^{2}$ & 0.261 & 0.283 \\
\hline
\end{tabular}

This table reports the result of the panel analysis and random effects model. Dependent variable (DIV): Ratio of cash dividends to total assets. DSCORE: Disclosure score collected from The Globe and Mail. DIV: Ratio of cash dividends to total assets; LAG(DIV): One-year lagged dividend; $\operatorname{Ln}(T A)$ : Natural logarithm of total assets; LEVERAGE: Ratio of total debt to total assets; ROE: Ratio of net income to shareholders' equity; CAPEXP: Ratio of capital expenditure to total assets; $M B$ : Ratio of market value of equity plus the book value of debt to the book value of assets; TAX: Ratio of income tax to total assets; RETAIN: Ratio of retained earnings to total equity; CASH: Ratio of cash and marketable securities to net assets, which are total assets minus cash and short-term securities; $F C F$ : Ratio of free cash flow to book value of assets. $t$-statistics are reported in parentheses. *,**,*** denote significance at the $10 \%, 5 \%$ and $1 \%$ levels, respectively.

\section{Conclusion}

This paper examines the effect of information disclosure on dividend policy for a sample of Canadian firms over the period 2009-2012. Based on the agency theory, this study tests two competing hypotheses: (1) the outcome hypothesis, which argues that dividends are an outcome of an effective governance regime and therefore dividend payouts would be higher in a transparent disclosure environment; and (2) the substitution hypothesis, which argues that dividend payout is a substitute for other forms of governance and would be higher in an opaque disclosure environment. The empirical evidence shows support for the outcome hypothesis. Firms with higher disclosure quality exhibit a stronger propensity to pay dividends and among dividend payers, they pay larger dividends. The results are robust to controlling for firm-specific characteristics, such as firms size, leverage, profitability, growth opportunities, investment opportunities, tax effect, retained earnings and availability of cash. The findings from 
this study also have unneglectable importance as they show that disclosure quality does matter to critical corporate decisions such as dividend policy. The implication for managers is that they should improve the disclosure quality of firms for the interests of shareholders who are then more likely to receive higher dividend payments. An extension of this paper could examine the linkage between disclosure quality and other corporate decisions such as corporate financing, equity issuance, and takeovers.

\section{References}

Abor, J., \& Fiador, V. (2013). Does corporate governance explain dividend policy in Sub-Saharan Africa? International Journal of Law and Management, 55(3), 201-225. http://dx.doi.org/10.1108/17542431311327637

Adjaoud, F., \& Ben-Amar, W. (2010). Corporate governance and dividend policy: Shareholders' protection or expropriation? Journal of Business Finance and Accounting, 37(5/6), 648-667. http://dx.doi.org/10.1111/j.1468-5957.2010.02192.x

Adjaoud, F., Zeghal, D., \& Andaleeb, S. (2007). The effect of board's quality on performance: A Canadian study. Corporate Governance: An International Review, 15(4), 623-635. http://dx.doi.org/10.1111/j.1467-8683.2007.00592.x

Araujo, A., Moreira, H., \& Tsuchida, M. (2011). Do dividend changes signal future earnings? Journal of Financial Intermediation, 20, 117-134. http://dx.doi.org/10.1016/j.jfi.2010.04.001

Armitage, S. (2012). Demand for dividends: The case of UK water companies. Journal of Business Finance and Accounting, 39(3/4), 464-499. http://dx.doi.org/10.1111/j.1468-5957.2011.02277.x

Arnold, A. J. (1998). UK accounting disclosure practices and information asymmetry during the first quarter of the twentieth century: The effects on book returns and dividend cover. Journal of Business Finance and Accounting, 25(7/8), 775-794. http://dx.doi.org/10.1111/1468-5957.00212

Avivazian, V., Booth, L., \& Cleary, S. (2003). Dividend policy and the organization of capital markets. Journal of Multinational Financial Management, 13(2), 101-121. http://dx.doi.org/10.1016/S1042-444X(02)00038-5

Avivazian, V., Booth, L., \& Cleary, S. (2006). Dividend smoothing and debt rating. Journal of Financial and Quantitative Analysis, 41(2), 439-453. http://dx.doi.org/10.1017/S0022109000002131

Bae, S. C., Chang, K., \& Kang, E. (2012). Culture, corporate governance, and dividend policy: International evidence. Journal of Financial Research, 35(2), 289-316. http://dx.doi.org/10.1111/j.1475-6803.2012.01318.x

Bartram, S. M., Brown, P. R., How, J. C. Y., \& Verhoeven, P. (2012). Agency conflicts and corporate payout policies: A global study. SSRN Working Paper. Retrieved from http://ssrn.com/abstract=1068281

Ben-Amar, W., \& Zeghal, D. (2011). Board of directors' independence and executive compensation disclosure transparency: Canadian evidence. Journal of Applied Accounting Research, 12(1), 43-60. http://dx.doi.org/10.1108/09675421111130603

Booth, L., \& Chang, B. (2011). Information asymmetry, dividend status, and SEO announcement-day returns. Journal of Financial Research, 34(1), 155-177. http://dx.doi.org/10.1111/j.1475-6803.2010.01287.x

Bozec, Y., \& Bozec, R. (2007). Ownership concentration and corporate governance practices: Substitution or expropriation effects? Canadian Journal of Administrative Sciences, 24(3), 182-195. http://dx.doi.org/10.1002/cjas.23

Brockman, P., \& Unlu, E. (2011). Earned/contributed capital, dividend policy, and disclosure quality: An international study. Journal of Banking and Finance, 35(7), 1610-1625. http://dx.doi.org/10.1016/j.jbankfin.2010.11.014

Bushman, R. M., \& Smith, A. J. (2001). Financial accounting information and corporate governance. Journal of Accounting and Economics, 31, 237-333. http://dx.doi.org/10.1016/S0165-4101(01)00027-1

Campbell, G., \& Turner, J. D. (2011). Substitutes for legal protection: Corporate governance and dividends in Victorian Britain. Economic History Review, 64(2), 571-597. http://dx.doi.org/10.1111/j.1468-0289.2010.00545.x

Chae, J., Kim, S., \& Lee, E. J. (2009). How corporate governance affects payout policy under agency problems and external financing constraints. Journal of Banking and Finance, 33(11), 2093-2101. http://dx.doi.org/10.1016/j.jbankfin.2009.05.003 
Chang, B., \& Dutta, S. (2012). Dividends and corporate governance: Canadian evidence. IUP Journal of Applied Finance, 18(4), 5-30.

Chen, L., Lin, C., \& Kim, Y.-C. (2011). Financial characteristics, corporate governance and the propensity to pay cash dividends of Chinese listed companies. International Business and Management, 3(1), 176-188.

Cheng, L. T. W., Davidson III, W. N., \& Leung, T. Y. (2011). Insider trading returns and dividend signals. International Review of Economics and Finance, 20, 421-429. http://dx.doi.org/10.1016/j.iref.2010.11.016

DeAngelo, H., \& DeAngelo, L. (2006). The irrelevance of the MM dividend irrelevance theorem. Journal of Financial Economics, 79, 293-315. http://dx.doi.org/10.1016/j.jfineco.2005.03.003

DeAngelo, H., DeAngelo, L., \& Stulz, R. M. (2006). Dividend policy and the earned/contributed capital mix: A test of the lifecycle theory. Journal of Financial Economics, 81, 227-254. http://dx.doi.org/10.1016/j.jfineco.2005.07.005

Denis, D., \& Osobov, I. (2008). Why do firms pay dividends? International evidence on the determinants of dividend policy. Journal of Financial Economics, 89, 62-82. http://dx.doi.org/10.1016/j.jfineco.2007.06.006

Easterbrook, F. H. (1984). Two agency-cost explanations of dividends. American Economic Review, 74(4), 650659.

Faccio, M., Lang, L. H. R., \& Young, L. (2001). Dividends and expropriation. American Economic Review, 91(1), 54-78. http://dx.doi.org/10.1257/aer.91.1.54

Fama, E. F., \& French, K. R. (2001). Disappearing dividends: Changing firm characteristics or lower propensity to pay. Journal of Financial Economics, 60, 3-43. http://dx.doi.org/10.1016/S0304-405X(01)00038-1

Fluck, Z. (1999). The dynamics of the management-shareholder conflict. Review of Financial Studies, 12, 347377. http://dx.doi.org/10.1093/rfs/12.2.379

Gelb, D. (1999). Accounting disclosures and corporate payout policy: Special dividends versus stock repurchases. Journal of Accounting, Auditing and Finance, 14(4), 385-399.

Gelb, D. S. (2000). Corporate signaling with dividends, stock repurchases, and accounting disclosures: An empirical study. Journal of Accounting, Auditing and Finance, 15(2), 99-120.

Gomes, A. (2000). Going public with asymmetric information, agency costs, and dynamic trading. Journal of Finance, 55, 615-646. http://dx.doi.org/10.1111/0022-1082.00221

Grullon, G., Michaely, R., \& Swaminathan, B. (2002). Are dividend changes a sign of firm maturity? Journal of Business, 75, 387-424. http://dx.doi.org/10.1086/339889

Guttman, I., Kadan, O., \& Kandel, E. (2010). Dividend stickiness and strategic pooling. Review of Financial Studies, 23(12), 4455-4495. http://dx.doi.org/10.1093/rfs/hhq096

Hu, A., \& Kumar, P. (2004). Managerial entrenchment and payout policy. Journal of Financial and Quantitative Analysis, 39(4), 759-790. http://dx.doi.org/10.1017/S0022109000003203

Hussainey, K., \& Aal-Eisa, J. (2009). Disclosure and dividend signalling when sustained earnings growth declines. Managerial Auditing Journal, 24(5), 445-454. http://dx.doi.org/10.1108/02686900910956801

Hussainey, K., \& Walker, M. (2009). The effects of voluntary disclosure and dividend propensity on prices leading earnings. Accounting and Business Research, 39(1), 37-55. http://dx.doi.org/10.1080/00014788.2009.9663348

Jensen, M. C. (1986). Agency costs of free cash flow, corporate finance, and takeovers. American Economic Review, 76(2), 323-329.

Jiraporn, P., \& Ning, Y. (2006). Dividend policy, shareholder rights, and corporate governance. Journal of Applied Finance, 16(2), 24-36.

Jiraporn, P., Kim, J.-C., \& Kim, Y. S. (2011). Dividend payouts and corporate governance quality: An empirical investigation. Financial Review, 46(2), 251-279. http://dx.doi.org/10.1111/j.1540-6288.2011.00299.x

John, K., \& Knyazeva, A. (2006). Payout policy, agency conflicts and corporate governance. Working Paper, New York University.

Klein, P., Shapiro, D., \& Young, J. (2005). Corporate governance, family ownership and firm value. Corporate Governance: An International Review, 13(6), 760-784.

Knyazeva, A. (2007). Delivering on the dividend promise: Corporate governance, managerial incentives and 
dynamic dividend behavior. Working Paper, New York University.

Kowalewski, O., Stetsyuk, I., \& Talavera, O. (2008). Does corporate governance determine dividend payouts in Poland? Post-Communist Economies, 20(2), 203-218. http://dx.doi.org/10.1080/14631370802018973

La Porta, R., Lopez-de-Silanes, F., Shleifer, A., \& Vishny, R. W. (2000). Agency problems and dividend policies around the world. Journal of Finance, 55(1), 1-33. http://dx.doi.org/10.1111/0022-1082.00199

Lang, M., Raedy, J. S., \& Wilson, W. (2006). Earnings management and cross listing: Are reconciled earnings comparable to US earnings? Journal of Accounting and Economics, 42, 255-283. http://dx.doi.org/10.1016/j.jacceco.2006.04.005

Lie, E. (2000). Excess funds and agency problems: An empirical study of incremental cash disbursements. Review of Financial Studies, 13(1), 219-248. http://dx.doi.org/10.1093/rfs/13.1.219

Lintner, J. (1956). Distribution of incomes of corporations among dividends, retained earnings and taxes. American Economic Review, 46, 97-113.

Miller, M. H., \& Rock, K. (1985). Dividend policy under asymmetric information. Journal of Finance, 40, 10311051. http://dx.doi.org/10.1111/j.1540-6261.1985.tb02362.x

Mitton, T. (2004). Corporate governance and dividend policy in emerging markets. Emerging Markets Review, 5(4), 409-426. http://dx.doi.org/10.1016/j.ememar.2004.05.003

Niu, F. F. (2006). Corporate governance and the quality of accounting earnings: A Canadian perspective. International Journal of Managerial Finance, 2(4), 302-327. http://dx.doi.org/10.1108/17439130610705508

Officer, M. S. (2006). Dividend policy, dividend initiations, and governance. Working Paper, University of Southern California.

Officer, M. S. (2011). Overinvestment, corporate governance, and dividend initiations. Journal of Corporate Finance, 17(3), 710-724. http://dx.doi.org/10.1016/j.jcorpfin.2010.06.004

Pinkowitz, L., Williamson, R., \& Stulz, R. M. (2007). Cash holdings, dividend policy, and corporate governance: A cross-country analysis. Journal of Applied Corporate Finance, 19(1), 81-87. http://dx.doi.org/10.1111/j.1745-6622.2007.00127.x

Renneboog, L., \& Trojanowski, G. (2007). Control structures and payout policy. Managerial Finance, 33(1), $43-$ 64. http://dx.doi.org/10.1108/03074350710715809

Sawicki, J. (2009). Corporate governance and dividend policy in Southeast Asia pre- and post-crisis. European Journal of Finance, 15(2), 211-230. http://dx.doi.org/10.1080/13518470802604440

Setia-Atmaja, L., Tanewski, G. A., \& Skully, M. (2009). The role of dividends, debt and board structure in the governance of family controlled firms. Journal of Business Finance and Accounting, 36(7/8), 863-898. http://dx.doi.org/10.1111/j.1468-5957.2009.02151.x

The Globe and Mail. (2012). Board Games 2012: Methodology. Retrieved from http://www.theglobeandmail.com/report-on-business/careers/management/board-games-2012/board-games-2 012-methodology/article5647746/?page=all

Twu, M. (2010). Prior payment status and the likelihood to pay dividends: International evidence. Financial Review, 45(3), 785-802. http://dx.doi.org/10.1111/j.1540-6288.2010.00271.x

\section{Copyrights}

Copyright for this article is retained by the author(s), with first publication rights granted to the journal.

This is an open-access article distributed under the terms and conditions of the Creative Commons Attribution license (http://creativecommons.org/licenses/by/3.0/). 